\title{
MIKRONUTRIEN PENYEBAB ANEMIA PADA PENGGUNA NARKOBA DI MEDAN TEMBUNG
}

\author{
Micronutrient Causes of Anemia in the Drugs Users in Medan Tembung \\ Ginta Siahaan ${ }^{1 *}$, Roy Ferdi Siallagan², Rumida Purba ${ }^{3}$, Riris Oppusungu ${ }^{4}$ \\ 1,3-4 Dosen Politeknik Kesehatan Kemenkes Medan, Jurusan Gizi \\ ${ }^{2}$ Alumni Politeknik Kesehatan Kemenkes Medan, Jurusan Gizi \\ E-mail: ginzsiahaan@gmail.com
}

\begin{abstract}
ABSTRAK
Pengguna narkoba umumnya rentan dengan masalah gizi yang disebabkan efek samping obat-obatan itu sendiri sehingga mengakibatkan penurunan nafsu makan dan terganggunya penyerapan zat gizi. Asupan zat gizi yang kurang, terutama zat gizi untuk pembentukan senyawa hemoglobin $(\mathrm{Hb})$ disinyalir merupakan penyebab utama pengguna narkoba mengalami anemia. Tujuan umum penelitian ini, untuk menganalisis hubungan asupan mikronutrien dengan kadar Hb pengguna narkoba di Kecamatan Medan Tembung. Jenis penelitian ini bersifat Observasional dengan desain cross sectional. Jumlah responden pada penelitian ini adalah 73 pengguna narkoba yang dipilih menggunakan teknik snowball dan accidental sampling. Data dianalisis menggunakan uji correlation pearson dan correlation rank spearman dilanjutkan dengan uji regresi linier untuk mengetahui variabel yang menjadi penyebab utama rendahnya kadar $\mathrm{Hb}$. Ada hubungan asupan mikronutrien seperti besi (Fe), seng ( $\mathrm{Zn})$, vitamin B9, vitamin B12 dan vitamin $\mathrm{C}$ terhadap kadar $\mathrm{Hb}$ dimana nilai $\mathrm{p}<0,05$, sedangkan Asupan $\mathrm{Fe}$ merupakan penyebab utama terjadinya penurunan kadar $\mathrm{Hb}$ dengan nilai $\mathrm{r}=0,661$. Perlu dilakukan sosialisasi kesehatan tentang efek samping dari menggunakan narkoba yang dapat menganggu penyerapan dan gangguan proses metabolisme mikronutrien. Pengguna narkoba seharusnya juga menghindari konsumsi bahan makanan yang juga menyebabkan gangguan penyerapan mikronutrien seperti teh yang berdampak terhadap rendahya kadar $\mathrm{Hb}$.
\end{abstract}

Kata kunci: asupan mikronutrien, haemoglobin, pengguna narkoba

\begin{abstract}
Drug users are generally vulnerable to malnutrition because of the side effects of drugs itself that has resulted in appetite reduction and nutrients malabsorption. Inadequate nutrient intake especially nutrient for haemoglobin synthesis is the main cause of anemia among drug users. The aim of this research was to analyze the relationship between intake of micronutrients and haemoglobin level among drug users in Medan Tembung Sub District. This research was an observasional study with cross sectional design. The respondents was 73 drug users selected by snowball and accidental sampling technique. Datas were analyzed using the pearson correlation test and rank spearmean correlation followed by linier regression test to analyze the main variables which cause the anemia. There was a relationship between the intake of micronutrients such as iron (Fe), zinc ( $\mathrm{Zn})$, vitamin B9, vitamin B12 and vitamin $C$ with the level of $\mathrm{Hb}$ where the value of $p<0.05$, while the Fe intake was the main cause of Hb depletion $(r=0.661)$. It is needed to do socialization of health related side effects for using drugs which may impair the absorption and metabolism of micronutrients. Drug users should avoid the consumption of micronutrient inhibitor such as tea which effect to the low level of $\mathrm{Hb}$.
\end{abstract}

Keywords: drug users, hemoglobin, micronutrients intake

\section{PENDAHULUAN}

Penyalahgunaan narkoba belakangan ini semakin lama semakin meningkat di Indonesia. Hal ini dapat dilihat dari jumlah kasus narkoba yang mengalami peningkatan dalam lima tahun terakhir. Kasus penggunaan narkoba di Sumatera Utara berdasarkan laporan BNN 2014 menduduki peringkat 4 di Indonesia tahun 2012. Gejala putus 
obat (withdrawal symptoms) pada pengguna narkoba berupa kecemasan, kegelisahan, depresi, serta gejala psikis lainnya berakibat fatal terhadap dirinya serta orang disekitar lingkungannya. Pemenuhan akan kebutuhan narkoba menimbulkan keberanian sehingga menuju terjadinya kriminalitas seperti pencurian, pencopetan, perkelahian, seks bebas bahkan pengguna narkoba tega membunuh orang (Eleanora, 2011).

Depresi menyebabkan terjadinya pola makan yang buruk seperti makan tidak beraturan dan jumlah asupan zat gizi yang tidak adekuat dari pengguna narkoba. Bila berlangsung lama dapat menyebabkan cadangan zat gizi di dalam tubuh terpakai, sehingga memengaruhi status gizi serta penurunan kadar hemoglobin ( $\mathrm{Hb})$. Asupan zat gizi yang kurang terutama yang berfungsi untuk pembentukan senyawa $\mathrm{Hb}$ disinyalir merupakan penyebab utama pengguna narkoba mengalami anemia. Zat gizi yang turut berperan dalam pembentukan kadar $\mathrm{Hb}$ adalah mikronutrien seperti zat besi $(\mathrm{Fe})$, seng $(\mathrm{Zn})$, vitamin B9 (asam folat), vitamin $\mathrm{B} 12$ (sianokobalamin) serta vitamin $\mathrm{C}$ (asam askorbat) (Wahyuningsih et al., 2014). Penelitian Islam et al. (2000) menyatakan narkoba menurunkan kadar $\mathrm{Hb}$ serta protein total darah.

Hasil penelitian Wahyuningsih et al. (2014) menemukan sebanyak $57,5 \%$ subjek mengalami anemia. Hasil penelitian lain di Dhaka Bangladesh, menyebutkan bahwa $60 \%$ dari pecandu narkoba mengalami anemia dan narkoba berpengaruh nyata menurunkan kadar $\mathrm{Hb}$ (Islam, 2000).

NAPZA atau yang lebih populer dikenal dengan istilah narkoba merupakan pemakaian jenis narkotika, obat-obat berbahaya serta alkohol (BNN, 2014). Efek samping penggunaan, NAPZA terhadap gangguan pembentukan $\mathrm{Hb}$ baik secara langsung atau tidak lagsung berbeda-beda tiap jenisnya (Nasution, 2014). Narkoba juga dapat menimbulkan meningkatkan radikal bebas dalam tubuh seperti Reactive Oxygen Species (ROS) dan zat ini dapat menyebabkan kerusakan pada membran sel termasuk diantaranya sel darah merah, sel hati dan juga pada sel gastrointestinal (Fitria et al., 2013).

Nikotin dan tar yang terkandung pada rokok yang biasa digunakan para pengguna narkotika jenis ganja, akan memberi stimulus peningkatan penggunaannya sebanyak empat kali dibanding orang yang tidak merokok (Rohsenow et al., 2005; Ismail, 2006; Astuti, 2016). Efek nikotin dan tar akan memengaruhi proses pembentukan sel-sel darah merah (hemopoiesis) dimana, terjadi kerusakan sumsum tulang dalam memproduksi sel darah merah (Safitri dan Fariani, 2015). Alkohol dapat menyebabkan kerusakan pada mukosa gastrointestinal yang dapat menghambat penyerapan $\mathrm{Fe}, \mathrm{Zn}$, vitamin $\mathrm{C}$ serta beberapa vitamin B (Mandangi et al., 2012 dan Kemenkes RI, 2014). Alkohol dan obat-obatan dapat merusak organ hati sehingga proses metabolisme beberapa zat gizi Fe, Zn, serta beberapa vitamin B kompleks dapat terganggu. Zat-zat gizi ini merupakan zat gizi utama dan zat gizi mikro yang membantu proses pembentukan $\mathrm{Hb}$ (Almatsier, 2009).

Narkoba jenis metaamphetamin yang terkandung di dalam sabu-sabu dan ecstasy memberikan dampak kehilangan nafsu makan, selain itu dapat menghambat penyerapan asupan Fe. Menurut penelitian Calarge et al. (2010) menunjukkan bahwa ada hubungan antara penurunan kadar feritin dalam tubuh dengan peningkatan penggunaan metaamphetamin. Menurunnya kadar feritin dalam tubuh menunjukkan bahwa cadangan Fe yang tersedia didalam hati tersedia dalam relatif rendah. Tujuan penelitian ini adalah menganalisis hubungan asupan mikronutrien dengan kadar $\mathrm{Hb}$ pada pengguna narkoba di Medan Tembung.

\section{METODE PENELITIAN}

Penelitian ini bersifat Observasional dengan rancangan penelitian cross sectional. Pelaksanaan penelitian dilakukan selama 2 bulan dari tanggal 1 Maret-31 Mei 2016.

Pengambilan subyek dilakukan dengan menggabungkan 2 teknik. Teknik yang pertama adalah snowball sampling yang artinya informasi dari mulut ke mulut dan diharapkan hadir ditempat pengambilan darah. Kehadiran dari pengguna narkoba dilanjutkan dengan teknik yang kedua yaitu accidental sampling yang merupakan teknik pengambilan sampel berdasarkan kebutuhan, yaitu siapa saja yang secara kebetulan bertemu dengan peneliti dapat digunakan sebagai sampel 
(Sastroasmoro dan Ismail, 2017). Subjek yang ditemui secara kebetulan dan sesuai dengan kriteria diambil sebagai responden. Penentuan responden dilakukan dengan kriteria inklusi;sudah menggunakan narkoba $\geq 6$ bulan, berjenis kelamin laki-laki, berumur antara 15-21 tahun, serta bersedia menjadi responden dengan mengisi informed consent, dapat diajak berkomunikasi dengan baik. Kriteria eksklusi seperti pengguna narkoba yang pernah direhabilitasi, dan berdomisili diluar Medan Tembung. Dari kriteria responden yang ditentukan diatas, maka ditemukan responden sebanyak 73 orang pengguna narkoba.

Pengumpulan data dilakukan dengan memperoleh data primer seperti identitas, data asupan mikronutrien dan data kadar Hb. Data sekunder diperoleh melalui pencatatan data dari dari Badan Narkotika Nasional (BNN) Sumatera Utara untuk mengetahui gambaran umum populasi penelitian.

Peneliti melakukan food recall selama 3 hari tidak berturut-turut. Pemilihan hari dilakukan hari Minggu, Selasa dan Jum'at. In depth interview dilakukan untuk mendapatkan informasi tambahan mengenai konsumsi makanan.

Data yang sudah dikumpulkan kemudian diolah menggunakan komputer secara manual melalui tahapan-tahapan proses yang dimulai dengan editing, entry, coding, cleaning dan tabulating data kemudian data dianalisis. Data asupan mikronutrien diolah dengan Nutrisurvey.

Pemeriksaan kadar $\mathrm{Hb}$ dilakukan dengan mengambil darah sebanyak $1,5-2$ cc dari nadi lengan sebelah kiri, kemudian dilakukan pemeriksaan dengan metode Cyanmethemoglobin dengan bantuan alat Spectrofotometry photometer 4010 Mannheim Boehringer dengan ketelitian $0,01 \mathrm{mg} / \mathrm{dl}$. Pengambilan darah dibantu oleh tenaga analis kesehatan, kemudian diperiksa di Laboratorium Kesehatan Daerah Sumatera Utara (LABKESDASU).

Analisis data pada penelitian ini terdiri analisis univariat, analisis bivariat dan analisis multivariat. Analisis univariat untuk menggambarkan masingmasing variabel yang disajikan dalam bentuk tabel frekuensi. Analisis bivariat menggunakan uji korelasi pearson untuk data yang terdistribusi normal berdasarkan uji kolmogrov smirnov, namun bila data yang diperoleh diketahui tidak terdistribusi normal, maka data tersebut akan dianalisis menggunakan uji korelasi rank spearman. Analisis multivariat dilakukan untuk mengetahui variabel bebas mana yang paling berpengaruh terhadap variabel terikat dengan uji statistik regresi linier (Siagian, 2010). Penelitian ini telah mendapatkan persetujuan etik dari Komite Etik Fakultas Kedokteran Universitas Sumatera Utara, No : 306/KOMET/FK USU/2016.

Tabel 1. Karakteristik Responden Berdasarkan Umur, Tingkat Pendidikan, Jenis Penggunaan Narkoba

\begin{tabular}{|c|c|c|c|c|c|}
\hline \multirow{2}{*}{ Karakteristik Responden } & \multirow{2}{*}{ Kategori } & \multicolumn{2}{|c|}{ Anemia } & \multicolumn{2}{|c|}{ Tidak Anemia } \\
\hline & & $\mathbf{n}$ & $\%$ & $\mathbf{n}$ & $\%$ \\
\hline \multirow[t]{2}{*}{ Umur } & 15-18 Tahun & 19 & 26,0 & 10 & 13,7 \\
\hline & 19-21 Tahun & 28 & 38,4 & 16 & 21,9 \\
\hline \multirow[t]{4}{*}{ Pendidikan } & $\mathrm{SD}$ & 4 & 5,5 & 5 & 6,9 \\
\hline & SMP & 11 & 15,1 & 5 & 6,9 \\
\hline & SMA & 12 & 16,4 & 6 & 8,2 \\
\hline & Perguruan Tinggi & 20 & 27,4 & 10 & 13,7 \\
\hline \multirow[t]{3}{*}{ Lama Penggunaan Narkoba } & $<12$ Bulan & 16 & 21,9 & 10 & 13,7 \\
\hline & 12-24 Bulan & 16 & 21,9 & 8 & 11,0 \\
\hline & $>24$ Bulan & 15 & 20,6 & 8 & 11,0 \\
\hline \multirow[t]{5}{*}{ Jenis Narkoba } & Sabu-sabu & 11 & 15,1 & 11 & 15,1 \\
\hline & Sabu-sabu dan Lem & 9 & 12,3 & 3 & 4,1 \\
\hline & Sabu-sabu dan Ganja & 21 & 28,8 & 10 & 13,7 \\
\hline & Sabu-sabu dan Ecstasy & 5 & 6,9 & 2 & 2,7 \\
\hline & Sabu-sabu dan Heroin & 1 & 1,4 & 0 & 0,0 \\
\hline
\end{tabular}




\section{HASIL DAN PEMBAHASAN}

\section{Karakteristik Responden}

Secara keseluruhan, sebagian besar responden berumur $19-21$ tahun $(60,27 \%)$ dan memiliki pendidikan PT $(41,10 \%)$. Jenis narkoba yang paling banyak digunakan adalah sabu-sabu dan ganja masing-masing sebesar $30,1 \%$ dan $41,8 \%$. Lama menggunakan narkoba $<12$ bulan $(35,61 \%)$. Distribusi karakteristik responden dapat dilihat pada tabel 1.

Hasil penelitian menunjukkan bahwa lebih dari separuh pengguna narkoba mengalami anemia. Kelompok umur 19-21 tahun memiliki proporsi anemia $(38,4 \%)$ yang lebih tinggi dibandingkan umur 15-18 tahun (26,0\%). Hasil penelitian Sasanti (2015) juga menemukan bahwa pengguna narkoba umumnya berusia antara 14-21 tahun. Kelompok dewasa muda ini merupakan kelompok yang masih ingin mencari jati diri, sehingga ajakan teman-teman sebaya lebih cepat direspons. Golongan umur dewasa muda dari segi mentalitas juga masih labil, sehingga mereka merasa takut dikucilkan dari lingkungan pergaulannya. Hal inilah salah satu penyebab sehingga mereka terjerumus kedunia kriminal termasuk penggunaan narkoba (Pantjalina et al., 2014).

Hasil penelitian menunjukan tingkat pendidikan pengguna narkoba dengan persentase tertinggi adalah Perguruan Tinggi (PT) sebesar 41,1\% dengan persentase anemia sebesar $27,4 \%$ dan terendah tingkat Sekolah Dasar (SD) sebesar 12,3\% dengan persentase anemia sebesar 5,5\%. Pendidikan yang dilalui seseorang baik formal maupun non formal akan meningkatkan pengetahuan, sehingga diharapkan dapat mengontrol dirinya kearah perilaku yang lebih positif. Pendidikan memberikan informasi yang berhubungan dengan tingkat pengetahuan seseorang. Semakin tinggi pendidikan seseorang maka semakin baik pula menyaring informasi yang baik dan yang buruk (Langitan, 2007). Pada penelitian ini, tingkat pendidikan pengguna narkoba yang tinggi dimungkinkan karena peredaran narkoba tidak memandang tinggi rendahnya pendidikan untuk dijadikan korban dari pengedar narkoba (BNN, 2014).
Penelitian ini menemukan bahwa jumlah responden yang mengonsumsi kombinasi sabu-sabu dan ganja sebanyak 31 orang $(41,5 \%)$ dengan persentase anemia sebesar $28,8 \%$, sedangkan yang mengonsumsi sabu-sabu dengan ecstasy sebanyak 7 orang $(9,6 \%)$ dengan persentase anemia $6,9 \%$. Responden yang mengonsumsi sabu-sabu dengan lem sebanyak 11 orang $(16,4 \%)$ dengan persentase anemia sebesar $12,3 \%$ dan mengonsumsi sabu-sabu sebanyak 22 orang $(30,1 \%)$ dengan persentase anemia sebesar $15,1 \%$ serta mengonsumsi sabu-sabu dengan heroin adalah sebanyak 1 orang $(1,4 \%)$ dengan persentase anemia sebesar $1,4 \%$. Anemia banyak terjadi pada penguna kombinasi sabu-sabu dan ganja (28,8\%). Sabu-sabu memiliki efek menurunkan nafsu makan sehingga dapat menyebabkan iritasi pada saluran pencernaan. Hal ini dapat menyebabkan gangguan penyerapan mineral Fe serta vitamin B12 dibagian lambung dan duodenum. Pemakaian ganja biasanya digunakan bersama rokok yang dapat menyebabkan keracunan nikotin dan tar yang dapat memengaruhi proses pembentukan sel-sel darah merah (hemopoiesis) (Safitri dan Fariani, 2015).

Hasil ini tidak sejalan dengan penelitian Kurniawati et al. (2010) di Yogyakarta yang menyatakan bahwa pengguna narkoba mengonsumsi lebih dari satu zat adiktif sebanyak $52,3 \%$. Konsumsi sabu-sabu sedang marak digunakan oleh pengguna narkoba. Hal ini disebabkan efek langsung penggunaan sabu-sabu lebih cepat dari jenis narkoba lainnya (BNN, 2014). Efek sabu-sabu biasanya memberikan perasaan berani, percaya diri dan euforia yang berlebihan. Penelitian di Iran tahun 2012 menunjukan pemakaian narkoba jenis sabu-sabu meningkat dengan semakin mudah dan tersedia untuk didapatkan (Shekarchizadeh et al., 2012).

Penelitian ini juga menemukan bahwa lama penggunaan narkoba yang terbesar ada pada rentang waktu $<12$ bulan sebanyak 26 orang $(35,6 \%)$ dengan persentase anemia sebesar $21,9 \%$, kemudian diikuti dengan lama penggunaan $12-24$ bulan sebanyak 24 orang $(32,9 \%)$ dengan persentase anemia sebesar $21,9 \%$ dan lama penggunaan $>24$ bulan sebanyak 23 orang $(31,5 \%)$ dengan persentase anemia sebesar $20,6 \%$. 
Tabel 2. Distribusi Rata-Rata, Nilai Minimum dan Maksimum Mikronutrien serta Kadar Hb

\begin{tabular}{|c|c|c|c|c|c|c|c|}
\hline \multirow[t]{2}{*}{ Indikator } & \multirow[t]{2}{*}{ Minimum } & \multirow[t]{2}{*}{ Maksimum } & \multirow[t]{2}{*}{ Rata-rata } & \multirow[t]{2}{*}{ Sd } & \multicolumn{3}{|c|}{$\begin{array}{c}\text { Nilai Rujukan } \\
\text { (AKG dan Nilai Normal) menurut umur }\end{array}$} \\
\hline & & & & & 15 & $16-18$ & $>18$ \\
\hline Asupan Fe (mg) & 2,6 & 19,7 & 6,8 & 2,9 & 19,0 & 15,0 & 13,0 \\
\hline Asupan Zn (mg) & 2,8 & 36,6 & 9,0 & 7,0 & 18,0 & 17,0 & 13,0 \\
\hline Asupan Vitamin B9 $(\mu \mathrm{g})$ & 40,0 & 558,3 & 183,7 & 123,8 & 400,0 & 400,0 & 400,0 \\
\hline Asupan Vitamin B12 $(\mu \mathrm{g})$ & 1,0 & 38,2 & 3,2 & 2,9 & 2,4 & 2,4 & 2,4 \\
\hline Asupan Vitamin C (mg) & 4,7 & 107,1 & 55,4 & 31,2 & 75,0 & 90,0 & 90,0 \\
\hline Kadar $\mathrm{Hb}(\mathrm{g} / \mathrm{dL})$ & 8,4 & 18,7 & 12,1 & 2,0 & $14,0-18,0$ & $14,0-8,0$ & $14,0-18,0$ \\
\hline
\end{tabular}

Penyalahgunaan narkoba merupakan pola penggunaan yang bersifat merusak, dimana efek dari narkoba tersebut akan muncul dalam kurun waktu paling sedikitnya 6 bulan (Purnomowardani dan Koentjono, 2000). Hasil penelitian Islam (2002) menemukan bahwa $\mathrm{Hb}$ darah pengguna narkoba $>5$ tahun memiliki nilai yang sangat rendah bila dibandingkan kelompok yang baru mengonsumsi narkoba sekitar 1 tahun dan kelompok kontrol yang tidak mengonsumsi narkoba. Penelitian Islam (2002) menunjukkan bahwa toksisitas yang ditimbulkan narkoba akan merusak hati sebagai pusat metabolisme dan juga menyebabkan serum antioksidan menjadi rendah. Serum antioksidan yang sangat terpengaruh akibat narkoba adalah vitamin $\mathrm{C}$ dibandingkan serum antioksidan lain yang juga diukur (vitamin A dan vitamin E). Vitamin C berfungsi sebagai antioksidan dan maintenance beberapa sel diantaranya sel darah merah (Almatsier, 2009).

Hal lain yang ditemukan akibat konsumsi narkoba terlalu lama adalah dapat menurunkan respon imunitas dalam tubuh sehingga pengguna narkoba mudah terserang penyakit. Pengguna narkoba akan mengalami anoreksia (mual dan muntah) sehingga asupan zat gizi menjadi rendah. Gejala-gejala dan efek samping akibat narkoba ini akan berpengaruh terhadap beberapa pemeriksaan biokimia darah termasuk kadar $\mathrm{Hb}$ yang mengalami penurunan paling signifikan (Islam, 2002).

\section{Asupan Mikronutrien dan Kadar Hb}

Berdasarkan angka kecukupan gizi (AKG 2013), didapati rata-rata asupan zat gizi $\mathrm{Fe}, \mathrm{Zn}$, vitamin B9, vitamin B12 serta vitamin C masih dibawah standar AKG 2013 kecuali asupan vitamin $\mathrm{B} 12$. Rata-rata kadar $\mathrm{Hb}$ pengguna narkoba juga masih dibawah standar yang ditetapkan WHO. Rata-rata nilai minimun dan nilai maksimum asupan mikronutrien serta kadar $\mathrm{Hb}$ dapat dilihat pada tabel 2 .

Dari penelitian ini diketahui bahwa rata-rata asupan $\mathrm{Fe}$ responden penelitian adalah sebesar 6,8 mg dimana asupan Fe tertinggi 19,7 mg dan asupan $\mathrm{Fe}$ terendah adalah 2,6 mg. Rata-rata asupan $\mathrm{Zn}$ sebesar 9,0 mg, dimana asupan $\mathrm{Zn}$ tertinggi 36,6 mg dan asupan $\mathrm{Zn}$ terendah adalah 2,8 mg. Hasil penelitian ini menunjukkan bahwa asupan $\mathrm{Fe}$ dan $\mathrm{Zn}$ pada pengguna narkoba masih dibawah AKG 2013. Asupan Fe semua responden masih dibawah AKG 2013, sedangkan asupan Zn sebagian besar masih dibawah AKG 2013. Untuk vitamin B9 sebanyak 78\% asupannya dibawah AKG 2013, vitamin B12 sebanyak 58\% asupannya dibawah AKG 2013 dan vitamin C sebanyak 62\% asupannya dibawah AKG 2013.

Hasil in-depth interview, rendahnya asupan dapat disebabkan daya beli untuk makanan sangat rendah dan jarangnya responden pulang untuk makan bersama dengan keluarga.

Akibatnya sumber makanan kandungan $\mathrm{Fe}$ dan $\mathrm{Zn}$ menjadi rendah terutama yang berasal dari hewani. Bahan pangan hewani yang tinggi akan kandungan $\mathrm{Fe}$ dan $\mathrm{Zn}$ adalah ikan laut, kerang-kerangan dan daging, sedangkan yang berasal dari nabati seperti kacang-kacangan serta sayuran hijau kurang begitu disukai serta dianggap makanan bermutu rendah.

Hasil penelitian menunjukkan asupan vitamin larut air pada pengguna narkoba masih dibawah standar AKG 2013. Berdasarkan hasil wawancara secara mendalam, keinginan untuk membeli makanan sangat rendah serta jarangnya mereka berkumpul dengan keluarga untuk makan bersama 
merupakan beberapa penyebabnya rendahnya asupan vitamin C. Hal lain yang memungkinkan rendahnya asupan vitamin larut air adalah rendahnya pengetahuan mereka tentang kebutuhan vitamin larut air serta sumbernya.

Hasil penelitian juga menunjukkan bahwa rata-rata kadar hemoglobin pada sampel adalah $12,1 \mathrm{~g} / \mathrm{dl}$ dengan kadar $\mathrm{Hb}$ minimum sebesar $8,4 \mathrm{~g} / \mathrm{dl}$ dan maksimum $18,7 \mathrm{~g} / \mathrm{dl}$. Rata-rata kadar $\mathrm{Hb}$ pengguna narkoba kurang dari standar normal kadar $\mathrm{Hb}$ untuk laki-laki (>13 g/dl), kriteria berdasarkan standar WHO (2001). Konsumsi makanan yang sedikit akan memengaruhi kadar $\mathrm{Hb}$ seseorang menjadi rendah. Hasil ini sejalan dengan penelitian Islam et al. (2000) di Dhaka yang menyebutkan bahwa $60 \%$ dari pecandu narkoba mengalami anemia dan narkoba berpengaruh nyata menurunkan kadar $\mathrm{Hb}$. Anoreksia akibat yang ditimbulkan narkoba akan berpengaruh terhadap rendahnya asupan mikronutrien dan juga menurunkan konsentrasi serum antioksidan dalam tubuh (vitamin C). Gangguan kesehatan lain pada pengguna narkoba adalah mengalami penyakit gastritis. Kondisi ini terjadi karena adanya perubahan pola makan dengan perut yang sering kosong. Mual, muntah dan perut kembung serta iritasi lambung akan menyebabkan asupan zat gizi berkurang dan penyerapannya terganggu (Islam, 2002; Almatsier, 2009).

Narkotika (ganja, sabu-sabu, ecstasy) serta obat-obat berbahaya akan meningkatkan stress oksidatif akibat radikal bebas dari konsumsi narkoba. Radikal bebas akan menyebabkan kerusakan pada organ hati yang berperan dalam proses metabolisme zat gizi ( $\mathrm{Fe}, \mathrm{Zn}$, vitamin B9, vitamin B12 dan vitamin C) sehingga dapat menurunkan pembentukan $\mathrm{Hb}$ (Fitria et al., 2013). Kerusakan pada sistem saluran cerna, akan mengiritasi lambung serta usus halus yang dapat menyebabkan terganggunya absorbsi dari mikronutrien pembentuk $\mathrm{Hb}$ (Almatsier, 2009). Gangguan lain akibat radikal bebas dapat menyebabkan penurunan hormon eritropoetine yang berfungsi membantu proses sintesa eritosit (sel darah merah) dan merupakan komponen yang pada $\mathrm{Hb}$. Radikal bebas yang disebabkan narkoba juga dapat menyebabkan terjadinya hemolisis.
Fenomena ini juga diduga turut menjadi penyebab rendahnya kadar $\mathrm{Hb}$ (Safitri dan Fariani, 2015).

Efek samping dari narkoba dapat menyebabkan penggunannya tidak dapat tidur hingga berhari-hari. Gangguan tidur, kemungkinan dapat menyebabkan perut kembung serta rasa mual sehingga dapat menyebabkan asupan mikronutrien menjadi rendah. Bila dihubungkan dengan hasil penelitian, terlihat bahwa rata-rata asupan $\mathrm{Fe}$ berada di bawah AKG 2013, sedangkan asupan Zn hanya $18 \%$ total asupannya diatas AKG 2013. Pada vitamin B9 sebanyak 78\% asupannya dibawah AKG 2013, vitamin B12 sebanyak 58\% asupannya dibawah AKG 2013 dan vitamin C sebanyak 62\% asupannya dibawah AKG 2013. Berdasarkan klasifikasi Gibson (2005) rata-rata asupan $\mathrm{Fe}$ semua inadekuat, sedangkan $\mathrm{Zn}$ hanya $7 \%$ yang adekuat. Pada kelompok vitamin, asupan vitamin B9 yang inadekuat sebanyak $84 \%$, asupan vitamin B12 yang inadekuat $65 \%$ dan asupan vitamin C yang inadekuat sebanyak $79 \%$.

\section{Hubungan Mikronutrien dengan Kadar $\mathbf{H b}$}

Mikronutrien merupakan komponen yang sangat penting, meskipun kebutuhannya sedikit bagi tubuh. Beberapa mikronutrien merupakan komponen penting bagi pembentukan sel-sel darah merah seperti Fe, Zn, vitamin B9, vitamin B12 dan vitamin $\mathrm{C}$.

Tabel 3 menunjukan adanya hubungan asupan mikronutrien dengan kadar $\mathrm{Hb}$ pada pengguna narkoba $(\mathrm{p}<0,05)$. Asupan $\mathrm{Fe}$ mempunyai keeratan hubungan yang paling kuat dengan kadar $\mathrm{Hb}$ yaitu $\mathrm{r}=0,583$.

$\mathrm{Hb}$ merupakan pigmen dalam darah yang berfungsi memberi warna merah pada darah dan mempunyai kapasitas untuk membawa oksigen

Tabel 3. Hasil Uji Bivariat Hubungan Mikronutrien dengan Kadar $\mathrm{Hb}$

\begin{tabular}{lccc}
\hline \multicolumn{1}{c}{ Indikator } & n & r & p-value \\
\hline Asupan Fe & 73 & 0,583 & $0,001^{*}$ \\
Asupan Zn & 73 & 0,447 & $0,004^{*}$ \\
Asupan Vitamin B9 & 73 & 0,501 & $0,003^{*}$ \\
Asupan Vitamin B12 & 73 & 0,434 & $0,014^{*}$ \\
Asupan Vitamin C & 73 & 0,353 & $0,032^{* *}$ \\
\hline
\end{tabular}

* Uji Korelasi rank Spearmen

**Uji Korelasi Pearson 
maupun karbon dioksida. $\mathrm{Hb}$ mengandung besi yang disebut heme dan protein globulin (Indartanti dan Apoina, 2014). Pada penelitian ini ditemukan rata-rata $\mathrm{Hb}$ pengguna narkoba masih dibawah standar normal yang ditetapkan oleh WHO tahun 2005. Konsumsi makanan yang rendah akan kandungan unsur zat gizi pembentuk $\mathrm{Hb}$ darah $(\mathrm{Fe}$, $\mathrm{Zn}$, vitamin B9, B12 serta vitamin C) merupakan faktor yang menyebabkan seseorang menderita anemia (Almatsier, 2009). Hasil ini sejalan dengan penelitian yang dilakukan oleh Islam tahun 2000, yang menyatakan bahwa $60 \%$ pecandu narkoba mengalami anemia dan narkoba berpengaruh terhadap penurunan kadar $\mathrm{Hb}$ (Islam, 2000)

Nilai $p$ value untuk hubungan antar variabel menunjukan bahwa asupan $\mathrm{Fe}$ dengan kadar $\mathrm{Hb}$ adalah $\mathrm{p}=0,001$, asupan $\mathrm{Zn} \mathrm{p}=0,004$, asupan vitamin $B$ 9 $p=0,003$, asupan vitamin $B 12 p=0,014$ dan asupan vitamin $\mathrm{C} p=0,032$. Fe merupakan komponen penting dari sel darah merah $(70 \%$ dari total $\mathrm{Fe}$ dalam tubuh), sekitar $25 \%$ total $\mathrm{Fe}$ tubuh tersimpan terutama dalam hati. Selebihnya, terserap pada sel-sel retikulo endotelial dalam sumsum tulang dan limpa (Istiqomah, 2009).

Fe merupakan komponen utama yang memegang peranan penting dalam pembentukan darah (hemopoiesis) yaitu molekul hemoglobin. Simpanan $\mathrm{Fe}$ dalam tubuh (ferritin dan hemosiderin) terdapat pada hati $30 \%$, sumsum tulang (30\%), dan selebihnya disimpan didalam limpa dan otot. Absorbsi mineral Fe dalam bentuk nonhem juga dapat meningkat 4 kali lipat bila terdapat vitamin C. Bila simpanan Fe berkurang dan jumlah $\mathrm{Fe}$ yang diperoleh dari makanan kurang dari kebutuhan, maka akan terjadi ketidakseimbangan Fe didalam tubuh, yang pada akhirnya menyebabkan anemia gizi besi (AGB). Ketidakcukupan asupan $\mathrm{Fe}$ pada pengguna narkoba disebabkan karena efek dari narkoba yang mengakibatkan penggunanya tidak nafsu makan selama berhari-hari (Cendani dan Murbawani, 2011; Dalimunthe, 2014). Penelitian ini juga sesuai dengan penelitian Hossain et al. (2007) yang menyatakan bahwa narkoba secara signifikan menurunkan konsentrasi Fe dalam tubuh.

Zn memegang peranan penting dalam banyak fungsi tubuh, sebagai bagian dari enzim. Zn juga diperlukan didalam aktivitas enzim superoksida dismutase (SOD) yang memiliki peranan penting dalam sistem pertahanan tubuh, terutama terhadap aktivitas senyawa oksigen reaktif yang banyak dihasilkan akibat pemakaian narkoba (Wintergrest et al. 2007). Toksisitas yang diakibatkan narkoba berupa stres oksidatif, akan dapat memengaruhi antioksidan enzimatis dalam bekerja dan juga membutuhkan alat transpot transferin yang merupakan alat transport $\mathrm{Fe}$ sekaligus dalam proses absorbsi Zn didalam tubuh (Almatsier, 2009). $\mathrm{Zn}$ juga merupakan bahan sintesis heme serta ditemukan dalam sel darah merah. Zn berinteraksi langsung dengan Fe sebagai kofaktor enzim amino levuline acid (ALA) yang berperan dalam sintesis heme saat berada pada sitosol sel sumsum tulang (Murray et al., 2009).

Vitamin B9 yang juga biasa disebut dengan folasin, merupakan salah satu unsur zat gizi yang memegang peranan dalam pembentukan $\mathrm{Hb}$. Vitamin B9 bersirkulasi langsung sebagai poliglutamat didalam pool (simpanan) sel darah merah. Kekurangan vitamin B9 akan mengakibatkan penekanan proliferasi sumsum tulang dalam pembentukan eritrosit (Almatsier, 2009). Vitamin B9 juga dibutuhkan dalam berbagai reaksi biokimia tubuh yang melibatkan pemindahan 1 unit karbon dalam inter konversi asam amino atau pada sintesis prekursor DNA pada proses eritropoesis yaitu proses pembentukan sel-sel darah merah (Mito et al., 2007).

Vitamin B12 juga berperan dalam pembentukan sel darah merah. Keberadaan vitamin ini lebih banyak ditemukan pada bahan pangan hewani dan penyerapannya lebih mudah dibandingkan vitamin B12 yang berasal dari bahan nabati. Pada pembentukan Hb, vitamin B12 membantu dalam proses metabolisme penyerapan Fe. Vitamin B12 juga membantu metabolisme vitamin B9 dengan merubahnya dalam bentuk aktif (Almatsier, 2009). Vitamin B12 juga merupakan senyawa penting dalam sintesis DNA bersama vitamin B9 yaitu akan memengaruhi regenerasi seluler dan akan mengakibatkan terjadinya anemia makrositik, dimana ukuran sel-sel darah merah menjadi besar (Setyawati dan Syauqy, 2014).

Vitamin larut air lainnya yang membantu pembentukan $\mathrm{Hb}$ adalah vitamin C. Peranan 
vitamin $\mathrm{C}$, menjaga keutuhan membran eritrosit yang kaya akan asam lemak tak jenuh yang rentan terjadinya peroksidasi lipid. Almatsier (2009) menyatakan bahwa vitamin C berperan untuk mereduksi ion ferri menjadi ferro dalam usus halus (duodedenum), sehingga lebih mudah diserap. Absorbsi terutama terjadi dibagian atas usus halus dengan bantuan alat angkut protein khusus, yaitu transferrin dan feritin. Absorbsi zat besi dalam bentuk nonheme meningkat 4 kali lipat bila konsumsi vitamin $\mathrm{C}$ terpenuhi. Vitamin $\mathrm{C}$ juga dibutuhkan untuk menghambat hemosiderin yang sukar dimobilisasi untuk membebaskan Fe bila diperlukan. Defesiensi vitamin $\mathrm{C}$ akan dapat menyebabkan kerusakan hipocampus (Pernile et al., 2012).

Narkoba yang dikonsumsi penggunanya dalam bentuk narkotika, obat-obatan berbahaya termasuk alkohol dan rokok dapat merusak berbagai komponen dalam tubuh seperti organorgan tubuh dan beberapa sel diantaranya saluran cerna, hati, sel darah merah serta hormon. Narkoba menyebabkan peningkatan radikal bebas dalam tubuh serta racun yang sangat berbahaya bagi aktivitas organ-organ tubuh serta merusak beberapa sel. Efek yang ditimbulkan berupa penurunan hormon erythropoiten yang membantu pembentukan sel darah merah $(\mathrm{Hb})$, menghambat pembentukkan beberapa vitamin diantaranya vitamin B12, vitamin B9, vitamin C serta beberapa mineral seperti Zn dan Fe (Almatsier, 2009).

Toksin dan radikal bebas yang dihasilkan narkoba dapat menyebabkan penurunan asam folat dalam RBC (Red Blood Cell). Hal ini kemungkinan terjadi peningkatan aktivitas dari hepatic microsomal oxidases yang diinduksi oleh polycyclic aromatic carbon hydrates yang terdapat pada narkoba (Leifert, 2008).

Berdasarkan in-depth interview serta hasil food recall, sebagian besar pengguna narkoba jarang mengonsumsi makanan sumber pembentuk Hb. Selain itu kemauan untuk membeli makanan yang sehat dan cukup mengandung gizi sangat rendah, ini kemungkinan disebabkan mereka lebih mementingkan pembelian narkoba dari pada membeli makanan. Bila mereka membeli makanan, biasanya mereka tidak tahu makanan apa yang dapat meningkatkan kesegaran fisiknya. Konsumsi daging, tempe, kacang-kacangan, sayuran hijau serta buah-buahan sangat jarang dikonsumsi. Mereka lebih suka membeli makanan yang mengenyangkan seperti nasi, lontong, mi instan dan roti bila efek samping dari pemakain narkoba sudah berkurang ataupun hilang. Efek lain dari narkoba seperti sabu-sabu yang dapat menyebabkan hilangnya nafsu makan, juga merupakan penyebab rendahnya konsumsi makanan (Wahyuningsih et al., 2014). Bila hal ini dibiarkan berlanjut akan dapat menyebabkan iritasi pada saluran pencernaan sehingga akan menganggu penyerapan zat gizi yang dibutuhkan untuk pembentukan $\mathrm{Hb}$ (Hossain et al., 2007). Hal lainnya yang juga ditemukan peneliti adalah para pengguna narkoba jarang pulang dan makan bersama dirumah, sehingga mikronutrien menjadi rendah karena tidak terkontrolnya jadwal makan (Wahyuningsih et al., 2014).

Uji multivariat dilakukan untuk mengetahui variabel yang paling berpengaruh dengan kadar $\mathrm{Hb}$ dengan melakukan analisis regresi linier berganda. Hasil uji multivariat dapat dilihat pada tabel 4. Hasil analisis regresi linier berganda pada tabel

Tabel 4. Hasil Uji Multivariat Asupan Mikronutrien dengan Kadar $\mathrm{Hb}$

\begin{tabular}{lccccc}
\hline Variabel dalam Model & Koefisien & Sd Error & Beta & T & $\boldsymbol{\rho}$ \\
\hline Konstanta & 8,689 & 0,543 & & 15,896 & 0,001 \\
Asupan Fe & 0,383 & 0,101 & 0,491 & 3,336 & 0,001 \\
Asupan Zn & 0,028 & 0,028 & 0,101 & 1,001 & 0,032 \\
Asupan Vitamin B9 & 0,004 & 0,002 & 0,257 & 2,187 & 0,022 \\
Asupan Vitamin B12 & 0,003 & 0,051 & 0,123 & 1,118 & 0,044 \\
Asupan Vitamin C & 0,008 & 0,006 & 0,128 & 1,275 & 0,047 \\
$\mathrm{R}$ & & & 0,661 & & \\
$\mathrm{R}^{2}$ & & & 0,473 & & \\
\hline
\end{tabular}


4 menunjukkan bahwa asupan $\mathrm{Fe}$ mempunyai pengaruh yang paling besar dibanding mikronutrien pembentuk Hb lainnya.

Pada penelitian ini nilai koefisien asupan Fe sebesar 0,383 akan menghasilkan konstanta $\mathrm{Hb}$ sebesar 8,869 g/dl artinya asupan $\mathrm{Fe}$ akan memengaruhi peningkatan $\mathrm{Hb}$ sebesar 8,869 kali bila dibandingkan asupan $\mathrm{Zn}$, vitamin B9, vitamin B12 dan vitamin C. Hasil ini sejalan dengan Hamiel et al. (2003) yang menyatakan bahwa ada hubungan yang signifikan antara tingkat kecukupan zat besi dengan status anemia. Asupan Fe merupakan komponen utama dalam pembentukan hemoglobin darah. Asupan vitamin $\mathrm{C}$ akan membantu proses penyerapan $\mathrm{Fe}$.

Pengguna narkoba jarang mengonsumsi sayur dan buah sebagai sumber vitamin C. Hasil in-depth interview menemukan bahwa kebiasaan minum teh susu telur (TST) pada pengguna narkoba, diduga juga dapat memperparah gangguan penyerapan $\mathrm{Fe}$. Susu mengandung kalsium dan teh mengandung tanin, kedua zat ini apabila dikonsumi bersamaan dengan sumber $\mathrm{Fe}$ akan menghambat penyerapan $\mathrm{Fe}$ yang terkandung didalam telur. Kandungan tanin didalam teh akan menghambat penyerapan Fe.

Seringnya konsumsi TST ini dapat dijadikan alternatif detoksifikasi efek samping narkoba, dapat meningkatkan stamina atau alternatif pasokan energi yang lebih cepat, setelah mereka mengalami penurunan efek halusinogen dari narkoba yang dikonsumsi. Keadaan inilah yang menyebabkan kadar $\mathrm{Hb}$ pengguna narkoba menjadi rendah, selain rendahnya asupan komponen $\mathrm{Fe}$ membentuk $\mathrm{Hb}$, juga diikuti kemungkinan tingginya asupan zat Inhibitor Fe didalam menu yang dikonsumsinya sehari-hari seperti oksalat dan fitat (Muwakhidah, 2009).

$\mathrm{Hb}$ mengandung $\mathrm{Fe}$ yang disebut heme dan protein globulin. Setiap molekul Hb mengikat oksigen untuk diedarkan keseluruh tubuh. Kurangnya asupan protein akan mengakibatkan transportasi Fe terhambat, sehingga akan terjadi defisiensi Fe. Absorbsi Fe yang terjadi di usus halus dibantu oleh alat angkut protein yaitu transferin dan feritin. Transferin mengandung Fe berbentuk ferro yang berfungsi mentransformasikan Fe ke sumsum tulang untuk pembentukan $\mathrm{Hb}$ (Webb, 2006).
Hasil ini didukung oleh penelitian Calarge et al. (2010) yang menunjukkan bahwa ada hubungan antara penurunan kadar feritin dalam tubuh yang diakibatkan oleh peningkatan konsumsi metaamphetamin yang terkandung dalam sabu-sabu dan ecstasy. Efek samping yang dihasilkan oleh narkoba (narkotika, obat-obat tar dan nikotin dalam rokok) dalam jangka waktu yang lama, akan menyebabkan rusaknya beberapa sel dan kerentanan terhadap tempat penyimpanan cadangan ferritin didalam hati. Cadangan ferritin merupakan gambaran konsekuensi fisiologis yang buruk terhadap asupan $\mathrm{Fe}$ yang rendah dalam jangka waktu lama. Saat konsumsi Fe dari makanan tidak cukup, Fe dari ferritin dikerahkan untuk memproduksi $\mathrm{Hb}$. Seseorang dengan asupan $\mathrm{Fe}$ yang rendah dalam jangka waktu yang lama, maka cadangan Fe didalam hatinya terjadi penurunan yang ditunjukan dengan menurunnya serum feritin (Vijayaraghavan, 2009).

Peningkatan stres oksidatif akibat narkoba juga akan meningkatkan radikal bebas, sehingga dapat merusak membran sel pada saluran cerna, hati dan sumsum tulang, kondisi ini akan mengganggu penyerapan $\mathrm{Fe}$ serta menghambat pembentukan $\mathrm{Hb}$ yang diakibatkan oleh rusaknya organ-organ tubuh (Almatsier, 2009). Radikal bebas menurunkan antioksidan didalam tubuh seperti penurunan glutation peroxidase (GPX), super oxide dismutase (SOD) yang berfungsi melindungi sel-sel didalam tubuh. Asupan vitamin $\mathrm{C}$ dan mineral $\mathrm{Zn}$ yang merupakan antioksidan eksogen asupannya rendah. Hal ini menyebabkan vitamin $\mathrm{C}$ dan $\mathrm{Zn}$ tidak dapat membantu mengeliminasi radikal bebas dari narkoba tidak mampu membantu penyerapan Fe terutama yang bersifat nonheme (Fitria et al., 2013).

\section{KESIMPULAN DAN SARAN}

Hasil penelitian menunjukkan kadar $\mathrm{Hb}$ pengguna narkoba berhubungan nyata dengan zat gizi mikronutrien ( $\mathrm{Fe}, \mathrm{Zn}$, vitamin $\mathrm{B}$ 9, vitamin B12 dan vitamin C). Asupan Fe memiliki pengaruh $(\mathrm{p}=0,000)$ terhadap kadar $\mathrm{Hb}$ pengguna narkoba dengan keeratan hubungan kuat $(\mathrm{r}=0,661)$, dibanding dengan asupan vitamin B9, asupan $\mathrm{Zn}$, asupan vitamin B12 dan asupan vitamin C. 
Dengan melihat kecenderungan peningkatan penggunaan narkoba dikalangan remaja diperlukan upaya pencegahan seperti sosialisasi kesehatan tentang hidup sehat dan penanggulangan masalah gizi serta dampak narkoba terhadap penyerapan zat gizi mikronutrien yang menyebabkan anemia. Disamping itu diperlukan upaya promosi kesehatan dalam pembuatan poster tentang pola makan yang baik bagi pengguna narkoba.

\section{DAFTAR PUSTAKA}

Almatsier, S. (2009). Prinsip dasar ilmu gizi. PT Gramedia Pustaka Utama. Jakarta.

Astuti, N. (2016). Merokok pintu masuk untuk penyalahgunaan narkoba jenis ganja. ARKESMAS 1(1). Diakses dari https://journal. uhamka.ac.id/index.php/arkesmas/article/ view/224/166.

BNN. (2014). Laporan akhir survei nasional perkembangan penyalahgunaan narkoba. Jakarta: Badan Narkotika Nasional.

Calarge, C., Cristian F., Robert, D., \& Eugene L.A. (2010). Serum ferritin and amphetamine respone in youth with attention-deficit/hyperactivitaminy disorder. Journal of Child and Adolescent Psychopharmacology. 20 (6). 495-502. Diakses dari www.ncbi.nlm.nih.gov/pmc/articles/ PMC3003494/.

Cendani, C. \& Murbawani, E.A. (2011) Asupan makronutrien, kadar hemoglobin, dan kesegaran jasmani remaja putri. Media Medika Indonesiana 45(1). Universitas Diponegoro.

Dalimunthe, A.N. (2014) Gambaran pola konsumsi pangan dan status gizi pada pecandu narkoba di panti sosial pamardi putra insyaf Sumatera Utara tahun 2014. (Skripsi, Universitas Sumatra Utara).

Eleanora, F.N. (2011). Bahaya penyalahgunaan narkoba serta usaha pencegahan dan penanggulangannya. Jurnal Hukum. 25(1).

Fitria., R.I.N.K., Retno, T., Jubhar C.M., \& Ferry F.K. (2013). Merokok dan oksidasi DNA. Sains Medika. 5 (2). 113-120.

Gibson, R.S. (2005). Principles of nutritional assessment. Second Edition. Oxford University Press Inc, New York.

Hamiel, O.P., Newfield, R.S., Koren, I., Agmon, A., Lilos. P., \& Phillip, M. (2003). Greater prevalence of iron deficiency in overweight and obese children and adolescents. International Journal of Obesity 27:416-418. Diakses dari https://www.nature.com/articles/0802224.pdf.

Hossain, K.J., Kamal, M.M., Ahsan, M., \& Islam, S.K.N. (2007). Serum antioxidant micromineral $(\mathrm{Cu}, \mathrm{Zn}, \mathrm{Fe})$ status of drug dependent subjects: influence of illicit drugs and lifestyle. Subtance Abuse Treatment, Prevention, and Policy 2(12). Diakses dari https://substanceabusepolicy. biomedcentral.com/articles/10.1186/1747597X-2-12

Indartanti, D., \& Apoina, K. (2014). Hubungan status gizi dengan kejadian anemia pada remaja putri. Journal of Nutrition College 3(2).

Islam, S.K.N, Hossain, K.J., \& Ahsan, M. (2000). Sexual lifestyle drug habit and socio demographic status of the drug addicts in Bangladesh. Public Health 114(5):389-92. Diakses dari http:// www.publichealthjrnl.com/article/S00333506(00)00369-3/pdf.

Islam, S.K.N., Hossain, K.J., Afsaruddin, A., \& Monira, A. (2002). Nutritional status of drug addicts undergoing detoxification: prevalence of malnutrition and influence of illicit durgs and lifestyle. British Journal of Nutrition. 88(5):50713. Diakses dari https://www.cambridge.org/core/ journals/british-journal-of-nutrition/article/ nutritional-status-of-drug-addicts-undergoingdetoxification-prevalence-of-malnutritionand-influence-of-illicit-drugs-and-lifestyle/ FC9B9244A13D232CDA25C1306567EE5E.

Ismail, A. (2006). Hubungan riwayat merokok dengan penyalahgunaan narkoba di indonesia (analisis data survei nasional penyalahgunaan dan peredaran gelap narkoba pada rumah tangga di indonesia tahun 2005). (Tesis, Universitas Indonesia).

Istiqomah, N. (2009). Hubungan tingkat kecukupan protein, besi dan vitamin $C$ dengan kadar hemoglobin. (Skripsi, Universitas Diponegoro). Diakses dari http://eprints.undip.ac.id/5817/.

Kemenkes RI. 2014. Pengguna narkoba dapat dicegah dan dapat direhabilitasi. Buletin Jendela Data dan Informasi Kesehatan. Semester I.

Kurniawati, D., Esti, W., Sri \& Raymondalexas, (2010). Gambaran skirining keterlibatan penggunaan alkohol, rokok dan zat adiktif pada mahasiswa d3 fakultas teknik Universitas Gadjah Mada. Berita Kedokteran Masyarakat 26 (2). 
Langitan, A. (2007). Persepsi remaja terhadap pencegahan perilaku minum alcohol di Kota Tomohon Provinsi Sulawesi Utara. (Tesis, Universitas Gadjah Mada, Yogyakarta).

Leifert, J.A. (2008). Anemia and cigarette smoking. Germany: Departement of Hematology and Oncology, University Medical Centre, Freiburg. Diakses dari http://www.Ncbi.nlm.nih.gov/ pubmed/18479294.

Mandangi, F., Shirley, K., \& Jane, M.P. (2012). Hubungan konsumsi alkohol dengan status gizi pada pria dewasa usia 30-40 tahun di desa kapoya kecamatan suluun tareran kabupaten Minahasa Selatan. SEMNAS FMIPA UNDIKSHA.

Mito, N., Takimoto, H., Umegaki, K., Ishiwaki, A., Kusama, K., Fukuoka. H., Ohta, S., Abe, S., Yamawaki, M., Ishida, H., \& Yoshiike, N. (2007). Folate intakes and folate biomaker profiles of pregnant japanese women in the first trimester. Eur J Clin Nutr. 61(1):83-90.

Murray, R.K., Granner, D.K., \& Rodwell, V.W. (2009). Happer's illustrated biochemistry (27th ed.) Dialihbahasakan oleh Brahm. Penerbit Buku Kedokteran. Jakarta.

Muwakhidah. (2009). Efek suplementasi fe, asam folat dan vitamin b12 terhadap peningkatan kadar hb pada pekerja wanita di Kabupaten Sukaharjo. (Tesis, Universitas Diponegoro).

Nasution, Z. (2014). Menyelamatkan keluarga indonesia dari bahaya narkoba. Bandung: Citrapustaka Media.

Pantjalina, L.E, Syafar, M., \& Natsir, S. (2014). Faktor memengaruhi perilaku pecandu penyalahgunaan napza pada masa pemulihan di Rumah Sakit Jiwa Daerah Atma Husada Mahakam Samarinda. (Tesis, Universitas Hasanuddin).

Pernile, T.N., Lucile, V., Janne, G.S., Nataline, J., Maya, D.P., Stephan, C., \& Jens, L. (2012). Maternal vitamin c deficiency during pregnancy persistenly impairs hippocampal neurogenis in off-spring of guinea pigs. Plos One 10(7):1-9.

Purnomowardani, A.D., \& Koentjoro. (2000). Penyikapan diri, perilaku seksual, dan penyalahgunaan narkoba. Jurnal Psikologi Universitas Gadjah Mada. 27(1).

Rohsenow, D.J., Colby, S.M., Martin, R.A., \& Monti, P.M. (2005). Nicotine and other subtance interaction expectancies questionnaire: relationship of expectancies to subtance use. Addictive Behaviour 30 (4):629-641. Diakses dari https://www.sciencedirect.com/science/ article/abs/pii/S030646030500002X.

Safitri, R.N., \& Fariani S. (2015). Resiko paparan asap rokok terhadap kejadian anemia pada ibu hamil. Jurnal Berkala Epidemiologi. 3(3).

Sasanti, S.D. (2015). Hubungan penyalahgunaan obat psikotropika dengan kejadian malnutrisi pada anak band di Kota Semarang. (Skripsi, Universitas Dian Nusantoro).

Sastroasmoro, S., \& Ismail, S. (2017). Dasar-dasar metode penelitian klinis Edisi II. Sagung Seto. Jakarta.

Setyawati, B., \& Syauqy, A. (2014). Perbedaan asupan protein, zat besi, asam folat, dan vitamin b12 anatara ibu hamil trimester III anemia dan tidak anemia di Puskesmas Tanggung Harjo Kabupaten Grobogan. J of Nutr College 3(1)

Shekarchizadeh, H., Hamed E., Mohammad R.K., \& Jorma I.V. (2012). Patterns of pre-treatment drug abuse, drug treatment history and characteristics of addicts in methadone maintenance treatment in Iran. Harm Reduction Journal 9:18. Diakses dari https://harmreductionjournal.biomedcentral. com/track/pdf/10.1186/1477-7517-9-18.

Vijayaraghavan, K. (2009). Gizi Kesehatan Masyarakat. Penerbit Buku Kedokteran EGC.

Wahyuningsih, U., Ali, K., \& Karina, R.E. (2014). Asupan zat gizi dan status anemia pada remaja laki-laki pengguna narkoba di lembaga permasyarakatan anak pria tangerang. Jurnal Gizi dan Pangan 9(1).

Webb, P. (2006). Dietary suplements and functional foods. UK: Blackwell Publissing.

Wintergrest, E.S, Silvia, M., Dietrich, H.. \& Horning. (2007). Contribution of selected vitamins and trace elements to immune function. Ann Nutr Metb 51(4):301-23.Diakses dari https://www. karger.com/Article/Abstract/107673. 